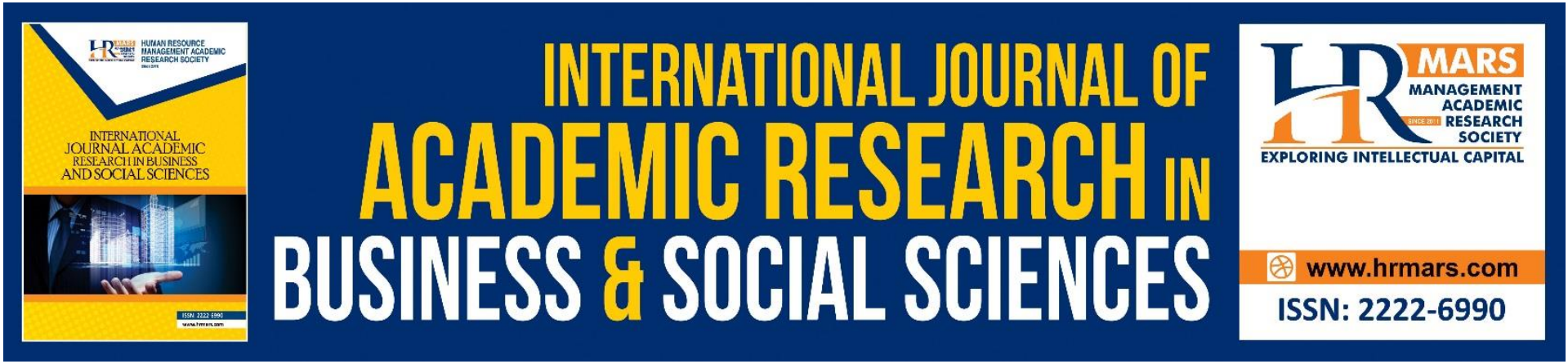

\title{
The Role of Justice in Government Institution and The Impact on Job Satisfaction
}

Siti Salwa Salim, Razaleigh Muhamat@Kawangit, Nurshahira Ibrahim, Azman Ismail

To Link this Article: http://dx.doi.org/10.6007/IJARBSS/v12-i1/11331

DOI:10.6007/IJARBSS/v12-i1/11331

Received: 07 November 2021, Revised: 08 December 2021, Accepted: 27 December 2021

Published Online: 12 January 2022

In-Text Citation: (Salim et al., 2022)

To Cite this Article: Salim, S. S., Muhamat@Kawangit, R., Ibrahim, N., \& Ismail, A. (2022). The Role of Justice in Government Institution and The Impact on Job Satisfaction. International Journal of Academic Research in Business and Social Sciences, 12(1), 408-420.

Copyright: (c) 2022 The Author(s)

Published by Human Resource Management Academic Research Society (www.hrmars.com)

This article is published under the Creative Commons Attribution (CC BY 4.0) license. Anyone may reproduce, distribute, translate and create derivative works of this article (for both commercial and non0-commercial purposes), subject to full attribution to the original publication and authors. The full terms of this license may be seen at: http://creativecommons.org/licences/by/4.0/legalcode

Vol. 12, No. 1, 2022, Pg. $408-420$

Full Terms \& Conditions of access and use can be found at http://hrmars.com/index.php/pages/detail/publication-ethics 


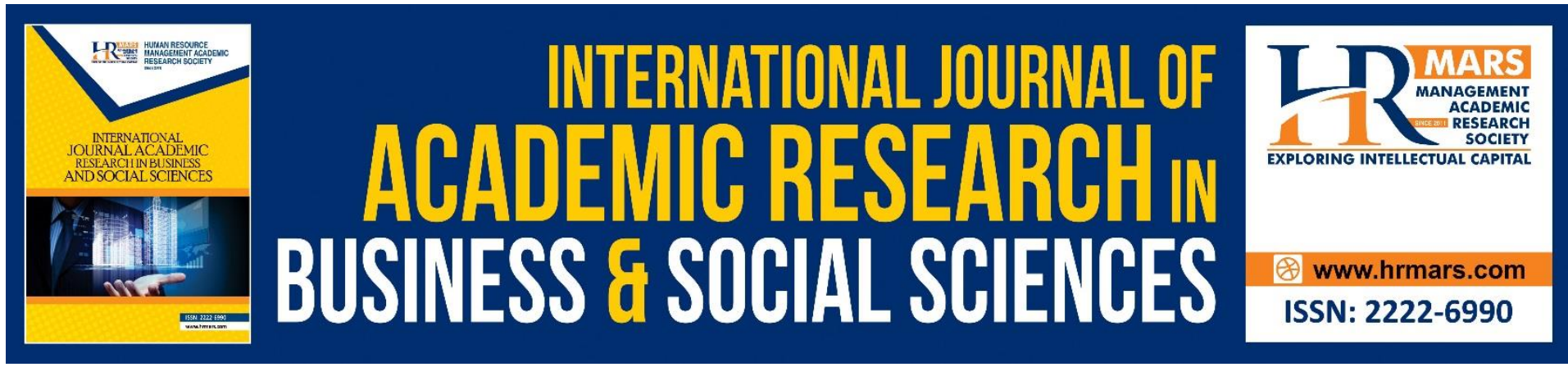

\title{
The Role of Justice in Government Institution and The Impact on Job Satisfaction
}

\author{
Siti Salwa Salim \\ Institute Islam Hadhari, Universiti Kebangsaan Malaysia
}

Razaleigh Muhamat@Kawangit

Institute Islam Hadhari, Universiti Kebangsaan Malaysia, Faculty of Islamic Studies, Universiti

Kebangsaan Malaysia

Nurshahira Ibrahim

Academy of Contemporary Islamic Studies Universiti Teknologi MARA Pahang, Malaysia

\section{Azman Ismail}

Faculty of Economic and Management, Universiti Kebangsaan Malaysia

Email: s.salwasalim@gmail.com

\begin{abstract}
In order to ensure an effective and successful organization, the aspect of justice must be upheld by every management. Management concerned about the issue of justice in the organization can change the organization in a positive direction to make the organization in a state with the principles, stance, and determination. This paper examines the relationship between organizational justice and job satisfaction. A survey method was employed to gather 164 questionnaires from Pejabat Setiausaha Kerajaan (SUK) Selangor employees. The outcomes of SmartPLS showed that procedural justice, distributive justice, and procedural justice might act as an essential antecedent of extrinsic job satisfaction. Besides, procedural justice and interactional justice also may act as an essential antecedent of intrinsic job satisfaction. Conversely, distributive justice does not have any significant relationship with intrinsic job satisfaction. Further, implication, discussion, and conclusion are elaborated.
\end{abstract}

Keywords: Procedural Justice, Distributive Justice, Interactional Justice, Job Satisfaction, Smart-PLS

\section{Introduction}

Justice is broadly defined as an act or decision aligned with moral value, religious teaching, and righteousness (Yuan, 2015). Meanwhile, organizational justice is often viewed as the individual perception of fairness (e.g., income, treatment, and decision making), which is it must be equitable with the outcomes of effort that has been contributing and allocated based on proper rules (Cook et al., 1997; Abd. Azis, 2010). According to Ridhwan \& Enah (2020), organizational justice is the concept that concerns fairness as it is directly related to the work 
environment. Besides, fairness is concerned based on two significant perspectives: outcomes that he/she receive from doing something and mean that used to obtain outcomes. The ability of managers to implement fairness in managing organizations work daily system may enhance workers' outcomes such as commitment and loyalty of workers toward organizations (Lambert et al., 2019), emotional intelligence (Paracha et al., 2017), organizational citizenship behavior (Donglong e al., 2019) and trust toward supervisor (Arif et al., 2020).

Organizational justice is one of the essential keys that may affect organizational effectiveness by enhancing positive behavior and productivity among employees (Purang, 2011; Nadiri \& Tanova, 2010). Based on the organizational behavior approach, organizational justice is about how an employee judges the treatment received from an organization or immediate supervisor and their behavioral reaction to such perception (Greenberg, 1987). According to Abd. Azis (2010), even though satisfying each employee is impossible, the implementation of justice in terms of management system on decision-making may minimize conflict in every decision made in the organization.

In the 1950s, the first dimension was coined in organizational justice: distributive justice originating from Adam's equity theory. This first dimension was concerned with the fairness in outcome distribution, whereas employees must be paid equally with their contribution (Phayoonpun \& Norazuwa, 2014). The inability of employers to meet this standard of contribution may negatively affect employee's behavior and attitude, such as being de-motivated to perform excellently (Yuan, 2015).

Later, procedural justice was introduced as the second dimension of organizational justice in the year of 1970s. This second dimension of justice deals with fairness in procedure, rules, and processes used to determine reward distribution (Azman et al., 20210). According to Krishnan (2020), procedural justice exists when employees find that decision-making is accurate, unbiased, correctable, and employees are allowed to voice their opinions in the field of work practice.

Then, in the mid-1980, interactional justice has begun to study by researchers as the second dimension of organizational justice. Interactional justice involves how immediate supervisors handled and treated their employees (Colquitt et al., 2005). When employees felt fairly treated, they would be more motivated in their task performance. According to Bies \& Moag (1986), interactional justice has four essential criteria: firstly, a justification that the supervisor/manager should briefly explain for decision making. Secondly, truthfulness is an explanation by supervisor/manager should be honest and open. Thirdly, propriety means that the supervisor/manager should avoid any improper statement when communicating with employees, and lastly is respect means that supervisors/managers should treat their employees with dignity and sincerity.

Lately, present literature highlighted that the ability of organizations or employers to implement justice in the organizational system properly might have a significant impact on employee's behavior, especially job satisfaction (Azman et al., 2021; Krishnan, 2020; Mohd Ridhwan \& Enah, 2020; Nawaz et al., 2018; Young et al., 2019). Numerous scholars such as Spector (1997) and McShane and VonGlinow (2005) describe job satisfaction as employees' perception of their job based on working conditions and environment. Employees with high satisfaction with their job may create a positive emotional state and contribute toward organizational performance. For this study, job satisfaction was divided into two-element that is intrinsic satisfaction and extrinsic satisfaction. Intrinsic satisfaction, also known as motivation factors, is defined as employees' perception about the internal aspects of their job (e.g., achievement, recognition, growth, and work itself) (Hezberg, 1966; Azman et al., 2011). 
Extrinsic satisfaction or hygiene factor is an employee's perception about an external factor of their job that may affect their job satisfaction (e.g., co-worker, job security, policies, and procedures) (Azman et al., 2011).

Although this relationship is fascinating, little is known about the role of organizational justice as an essential predictive variable in the literature on workplace justice. Many researchers claimed that prior studies paid insufficient attention to the predictive variable of organizational justice because they over-emphasized the internal qualities of organizational justice (e.g., definition, objective, type, and importance of organizational justice). Furthermore, previous research has primarily relied on a simple correlation method to assess general respondent attitudes toward organizational justice features, ignoring the importance of determining the magnitude of the relationship between the dimension of organizational justice and employee attitude and behavior in the workplace (Usmani \& Jamal, 2013; Rahman et al., 2015). As a result, those studies may not provide sufficient information for practitioners to develop strategic action plans for strengthening organizational justice program implementation in highly competitive firms. As a result, the researchers were inspired to learn more about nature's role in this interaction.

\section{Objective of Study}

This study has been conducted with six essential purposes, they are:

- Test the association between procedural justice and intrinsic job satisfaction

- Test the association between distributive justice and intrinsic job satisfaction

- Test the association between interactional justice and intrinsic job satisfaction

- Test the association between procedural justice and extrinsic job satisfaction

- Test the association between distributive justice and extrinsic job satisfaction

- Test the association between interactional justice and extrinsic job satisfaction

\section{Literature Review}

A direct effect model was used in several recent research to investigate the role of organizational justice based on different samples and different organizations' backgrounds. For instance, Qureshi et al (2016) used a sample of 827 police officers in north Indian, Afridi and Baloch (2018) used to sample 550 employees in public and private universities in Peshawar, Pakistan, Ridhwan \& Enah (2020) used a sample of 97 employees from the courier, and postal service provider in Malaysia, Purnama et al (2020) used 100 managers of banking company in Yogyakarta, Indonesia as a sample, Krishnan (2020) used the perception of 60 non-managerial employees in the manufacturing sector in SME's in Johor, Malaysia and Lambert et al (2019) used a sample of 322 responses of correctional in the U.S. The results from this literature have shown that the ability of superior managers or employers to implement fairness in organization management systems such as in determining reward distribution of employees, decision making about working environment, and interactional relationship with employees enhance employee's satisfaction intrinsically and extrinsically. Furthermore, these outcomes of studies have in line with Adam's (1963) equity theory which states that when an individual got an equitable outcome (e.g., pay, appraisal and treatment) with their contribution, it may give a positive influence on their behavior (e.g., job satisfaction). In addition, this story posits that when employees are treated fairly in terms of treatment by the supervisor or distribution of reward of punishment by the organization, it may enhance their satisfaction. Besides, the findings of these studies also gained strong support from Maslow's Hierarchy Need Theory (1943), which states that an individual has 
five-tier of hierarchy needs: psychological needs, safety, love and belonging, esteem, and selfactualization. For this study, the manager's ability or superior to implement justice in the organization, such as distributing employees' outcomes fairly that may cover their basic needs of life, may enhance employees' satisfaction since it was one of the five-tier hierarchy.

\section{Conceptual Framework and Research Hypothesis}

Based on the literature, a conceptual framework was developed as figure 1:

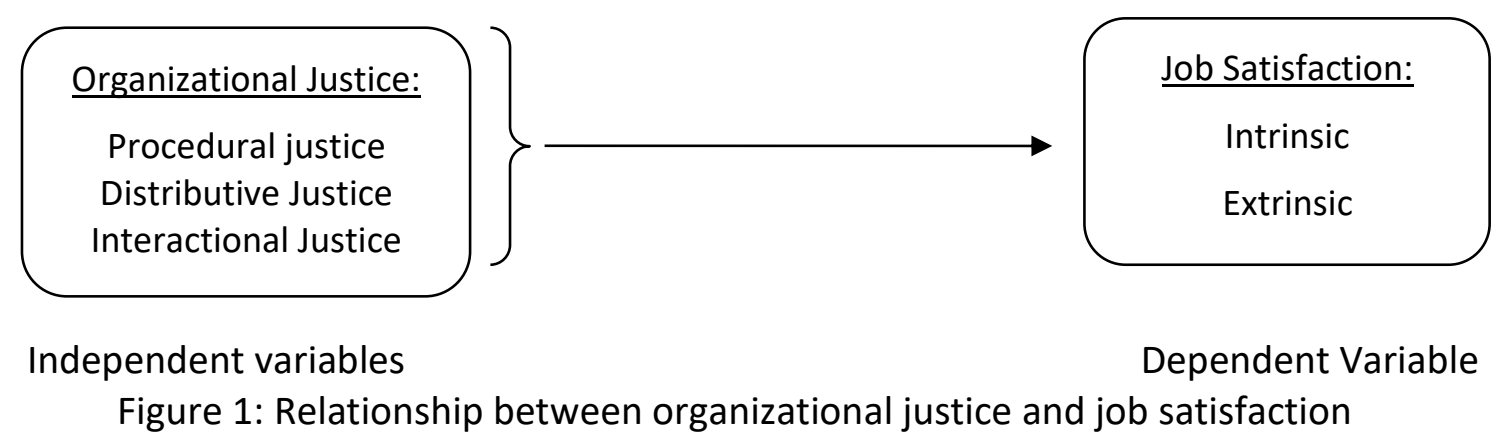

Based on the framework, it is possible to hypothesize that:

$\mathrm{H1}$ : Procedural justice positively related to intrinsic job satisfaction

$\mathrm{H} 2$ : Distributive justice positively related to intrinsic job satisfaction

H3: Interactional justice positively related to intrinsic job satisfaction

$\mathrm{H} 4$ : Procedural justice positively related to extrinsic job satisfaction

H5: Distributive justice positively related to extrinsic job satisfaction

H6: Interactional justice positively related to extrinsic job satisfaction

\section{Methodology}

\section{Research Design}

The researchers employed a cross-sectional research strategy in this work, which allowed them to incorporate organizational justice literature, a pilot study, and an actual survey as a data-gathering process (Sekaran \& Bougie, 2013). Implementing these processes can improve the quality and accuracy and lessen the bias of the data being collected (Azman et al., 2014). This study was conducted at Negeri Selangor's Pejabat Setiausaha Kerajaan (SUK). The researchers drafted the questionnaires survey on previous related literature at the start of this study. After reviewing the questionnaire with 15 employees during a pilot study, the substance and presentation of the surveys have improved. These individuals were chosen using the purposive sampling technique because they had 10 to 20 years of work experience and shown good knowledge and experience in the management of organizational justice in their organization. To strengthen the validity and reliability of the research findings, a backtranslation approach was utilized to translate the survey questionnaires into English and Malay languages (Sekaran \& Bougie, 2013).

\section{Measures}

The survey questionnaire had five sections. The first section is the questions about the respondent's demographic background. Second, procedural justice had five items adjusted from past literature in organizational justice (Nwibere, 2014; Al-Zu'bi, 2010; Neihoff \& Moorman, 1993). Example of questions are: "The procedures used to amend my organization's pay system is fair," "Supervisors/ officers make sure that all employee's 
concerns are heard before decisions are made' and "My supervisor/ officer is open-minded and consider my viewpoint"

Third distributive justice had five modified items from past literature (Chen et al., 2015; Niehoff \& Moorman, 1993). Some items are: "The overall reward/ incentive I receive are fairly distributed," "I believe that my rewards/ incentives accurately reflect my contributions to the organization," and "the rewards/ incentives I receive are based on my level of performance." Fourth interactional justice had five items adjusted from previous literature (Rahim et al., 2001; Bies \& Moag, 1986). Example items are: "My supervisor/ officer treats me with kindness and consideration" and "I believe that my supervisor's/ officer's actions show that $\mathrm{s} / \mathrm{he}$ respects me."

Fifth, job satisfaction is divided into intrinsic and extrinsic and modified from past literature (Nadiri and Tanova, 2010). Example items for intrinsic job satisfaction are: "I am satisfied with my job" and "I feel that my job is more interesting than others." While for extrinsic job satisfaction, some items are: "I am satisfied with my supervisor/ officer" and "I am satisfied with the relationship between the management and employees."

All of these items were assessed on a seven-point scale ranging from "very strongly disagree/dissatisfied" (1) to "very strongly agree/satisfied" (7). Since the focus of this study was on employee attitudes, demographic characteristics were employed as control variables. Sample

Five hundred survey questionnaires were sent to the organization's employees using the purposive sample technique. Because the researchers did not have detailed records about the staff at the organizations to choose them as participants in this study, this technique was used instead of random sampling. A total of 164 valid questionnaires were returned to the researchers, indicating a response rate of $32.8 \%$. Participants completed the survey questions voluntarily and with their agreement.

Data Analysis

SmartPLS version 3.3.2 was used to evaluate the survey questionnaire data because it can deliver latent variable scores, avoid minor sample size issues, estimate any model with many latent and manifest variables, deal with stringent assumptions about the distribution of variables and error terms, and handle both reflective and formative measurement models (Henseler et al., 2009).

\section{Result}

Table 1 shows most respondents were female (62.2\%), SPM holders (36.6\%), permanent workers $(66.5 \%)$, age between $26-35$ years $(54.9 \%)$, working experience $1-5$ years $(43.9 \%)$, and non-executive grade (72\%). 
Table 1 Profile of Respondent ( $n=164)$

\begin{tabular}{|c|c|c|c|}
\hline Sample Profile & Sub Profile & Frequency & Percentage (\%) \\
\hline \multirow[t]{4}{*}{ Gender } & Female & 102 & 62.2 \\
\hline & Male & 62 & 37.8 \\
\hline & Degree and above & 36 & 22.0 \\
\hline & Diploma & 33 & 20.1 \\
\hline \multirow[t]{4}{*}{ Education } & STPM/Matriculation & 24 & 14.6 \\
\hline & SPM & 60 & 36.6 \\
\hline & $\mathrm{PMR} / \mathrm{SRP}$ & 6 & 3.7 \\
\hline & Others & 5 & 3.0 \\
\hline \multirow[t]{4}{*}{ Type } & Permanent & 109 & 66.5 \\
\hline & Contract & 42 & 25.6 \\
\hline & Others & 13 & 7.9 \\
\hline & $18-25$ & 19 & 11.6 \\
\hline \multirow[t]{5}{*}{ Age } & $26-35$ & 90 & 54.9 \\
\hline & $36-45$ & 29 & 17.7 \\
\hline & 46 and above & 26 & 15.9 \\
\hline & Less than one year & 5 & 3.0 \\
\hline & 1-5 year & 72 & 43.9 \\
\hline Length of & 6-10 year & 42 & 25.6 \\
\hline \multirow[t]{2}{*}{ Service } & 11-15 year & 8 & 4.9 \\
\hline & 16 years and above & 37 & 22.6 \\
\hline \multirow[t]{2}{*}{ Grade } & Executive & 46 & 28.0 \\
\hline & Non-Executive & 118 & 72.0 \\
\hline
\end{tabular}

The results of factor loading and composite reliability analysis are shown in Table 2 . The outer loading value for each construct was more significant than 0.7 , indicating that the construct met the convergent validity analysis requirement (Hair et al., 2017). In the meantime, each construct has a composite reliability rating of better than 0.8 , indicating a high level of internal consistency (Hair et al., 2017).

Table 2 The Value of Factor Loading and Composite Reliability

\begin{tabular}{cccc}
\hline Constructs & No. of Items & Outer Loading & $\begin{array}{c}\text { Composite } \\
\text { Reliability }\end{array}$ \\
\hline $\begin{array}{c}\text { Procedural Justice } \\
\text { Distributive } \\
\begin{array}{c}\text { Justice } \\
\text { Interactional } \\
\text { Justice }\end{array}\end{array}$ & 5 & $\begin{array}{l}.829-.907 \\
.718-.889\end{array}$ & .946 \\
$\begin{array}{l}\text { Intrinsic Job } \\
\text { Satisfaction } \\
\text { Extrinsic Job }\end{array}$ & 5 & $.799-.888$ & .928 \\
Satisfaction & 3 & $.866-.904$ & .916 \\
\hline
\end{tabular}


The results of the convergent and discriminant validity analyses are shown in Table 3 . The average variance extracted (AVE) value for each variable was more significant than 0.50 , indicating that the constructs met the convergent validity analysis requirement (Forner \&Larcker, 1981). The value of the square root of AVE, also known as diagonal, should be more relevant than the value of off-diagonal figures for discriminant validity (Fornell \& Larckel, 1981; Henseler et al., 2009). Because the value of in diagonal is consistently higher than offdiagonal, the test for discriminant validity is valid for this result.

Table 3 Result for Convergent and Discriminant Validity Analysis

\begin{tabular}{|c|c|c|c|c|c|c|}
\hline Variable & AVE & $\begin{array}{l}\text { Procedura } \\
\text { I Justice }\end{array}$ & $\begin{array}{c}\text { Distributiv } \\
\text { e Justice }\end{array}$ & $\begin{array}{c}\text { Interactiona } \\
\text { I Justice }\end{array}$ & $\begin{array}{c}\text { Intrinsic } \\
\text { Job } \\
\text { Satisfactio } \\
n\end{array}$ & $\begin{array}{c}\text { Extrinsic } \\
\text { Job } \\
\text { Satisfactio } \\
n\end{array}$ \\
\hline $\begin{array}{l}\text { Procedural } \\
\text { Justice }\end{array}$ & $\begin{array}{c}.77 \\
8\end{array}$ & .882 & & & & \\
\hline $\begin{array}{l}\text { Distributive } \\
\text { Justice }\end{array}$ & $\begin{array}{c}.70 \\
0\end{array}$ & .872 & .837 & & & \\
\hline $\begin{array}{l}\text { Interactiona } \\
\text { I Justice }\end{array}$ & $\begin{array}{c}.72 \\
0\end{array}$ & .778 & .790 & .849 & & \\
\hline $\begin{array}{l}\text { Intrinsic Job } \\
\text { Satisfaction }\end{array}$ & $\begin{array}{c}.78 \\
4\end{array}$ & .822 & .784 & .769 & .885 & \\
\hline $\begin{array}{l}\text { Extrinsic Job } \\
\text { Satisfaction }\end{array}$ & $\begin{array}{c}.76 \\
0\end{array}$ & .846 & .825 & .766 & .812 & .872 \\
\hline \multicolumn{7}{|c|}{$\begin{array}{l}\text { The descriptive statistic and variance inflation factors are shown in Table } 4 \text {. Each variable's } \\
\text { mean value varies from } 5.3 \text { to } 5.5 \text {, indicating that most participants rated procedural justice, } \\
\text { distributive justice, interactional justice, intrinsic job satisfaction, and extrinsic job satisfaction } \\
\text { as high (4) to very high (7). Meanwhile, because the value of variance inflation factor between } \\
\text { the independent variable (i.e., procedural justice, distributive justice, and interactional } \\
\text { justice) and the dependent variable (i.e., intrinsic and extrinsic job satisfaction) was less than } \\
\text { 5.0, the data were not affected by severe collinearity (Hair et al., 2017). }\end{array}$} \\
\hline
\end{tabular}

Table 4 Collinearity Analysis and Descriptive Statistics

\begin{tabular}{lcccc}
\hline Variable & Mean & $\begin{array}{c}\text { Standard } \\
\text { Deviation }\end{array}$ & $\begin{array}{c}\text { Variance inflation factor (VIF) } \\
\text { Intrinsic job } \\
\text { satisfaction }\end{array}$ & $\begin{array}{c}\text { Extrinsic Job } \\
\text { Satisfaction }\end{array}$ \\
\hline $\begin{array}{l}\text { Procedural } \\
\text { Justice }\end{array}$ & 5.3 & 1.2 & 4.584 & 4.584 \\
$\begin{array}{l}\text { Distributive } \\
\text { Justice }\end{array}$ & 5.5 & 1.1 & 4.801 & 4.801 \\
$\begin{array}{l}\text { Interactional } \\
\text { Justice }\end{array}$ & 5.4 & 1.1 & 2.919 & 2.919 \\
$\begin{array}{l}\text { Intrinsic Job } \\
\text { Satisfaction }\end{array}$ & 5.4 & 1.2 & & \\
$\begin{array}{l}\text { Extrinsic Job } \\
\text { Satisfaction }\end{array}$ & 5.4 & 1.2 & & \\
\hline
\end{tabular}




\section{Outcomes of Hypothesis Testing}

The results of hypothesis testing using SmartPLS path model analysis are shown in Figure 2. Independent variables (i.e., procedural justice, distributive justice, and interactional justice) explained $72 \%$ of the variance in the independent variable (i.e., intrinsic job satisfaction). Simultaneously, the hypothesis testing reveals three significant findings. First, procedural justice ( $\beta=0.47 ; t=4.15$ ) was significantly and positively linked with intrinsic job satisfaction; thus, $\mathrm{H} 1$ was accepted. Second, intrinsic job satisfaction was not substantially connected with distributive justice ( $\beta=0.15 ; t=1.35$ ); hence $\mathrm{H} 2$ was rejected. Finally, intrinsic job satisfaction was positively and strongly linked with interactional justice $(\beta=0.27 ; t=2.16)$; H3 was accepted. In conclusion, our finding demonstrates that procedural and interactional fairness are essential determinants of intrinsic work satisfaction, although distributive justice is not.

Table 5: The outcome of the hypothesis testing between organizational justice and intrinsic job satisfaction

\begin{tabular}{|l|c|c|c|c|}
\hline \multicolumn{1}{|c|}{ Hypothesis } & $\boldsymbol{\beta}$ value & t value & $\mathbf{R}^{\mathbf{2}}$ & Decision \\
\cline { 1 - 3 } $\begin{array}{l}\text { H1: Procedural justice } \\
\text { Intrinsic job satisfaction }\end{array}$ & 0.47 & 4.15 & & Supported \\
\cline { 1 - 3 } $\begin{array}{l}\text { H2: Distributive justice } \rightarrow \\
\text { Intrinsic job satisfaction }\end{array}$ & 0.15 & 1.35 & 0.72 & Rejected \\
\cline { 1 - 3 } $\begin{array}{l}\text { H3: Interactional justice } \rightarrow \\
\text { Intrinsic job satisfaction }\end{array}$ & 0.27 & 2.16 & & Supported \\
\hline
\end{tabular}

\section{Note: Significant at $t>1.96$}

Further, the test of predictive relevance that using test Stone-Geisser's to test Q2 was carried out. The value of Q2 for intrinsic job satisfaction is 0.54 , which is greater than 0 , confirming that the model has predictive relevance (Hair et al., 2017).

Figure 3 presents the inclusion of independent variables (procedural justice, distributive justice, and interactional justice) and explains $76 \%$ of the variance independent variables (i.e., extrinsic job satisfaction). Hypothesis testing shows three critical outcomes. First, procedural justice was significantly associated with extrinsic job satisfaction ( $\beta=0.45 ; t=5.12$ ); thus, $\mathrm{H} 4$ was accepted, second distributive justice was significantly associated with extrinsic job satisfaction ( $\beta=0.27 ; t=2.58$ ); hence, $\mathrm{H} 5$ was accepted, third interactional justice was significantly associated with extrinsic job satisfaction $(\beta=0.19 ; \mathrm{t}=2.63)$; hence, H6 was accepted. In sum, this result confirms that procedural justice, distributive justice, and interactional justice act as an essential determinant of extrinsic job satisfaction.

Table 6: The outcome of the hypothesis testing between organizational justice and extrinsic job satisfaction

\begin{tabular}{|l|l|l|l|l|}
\hline Hypothesis & $\boldsymbol{\beta}$ value & t value & $\mathbf{R}^{\mathbf{2}}$ & Decision \\
\hline $\begin{array}{l}\text { H3: Procedural } \rightarrow \text { justice } \\
\text { Extrinsic job satisfaction }\end{array}$ & 0.45 & 5.12 & & Supported \\
\hline $\begin{array}{l}\text { H5: Distributive fustice } \\
\text { Extrinsic job satisfaction }\end{array}$ & 0.27 & 2.58 & 0.76 & Supported \\
\cline { 1 - 3 } $\begin{array}{l}\text { H6:Interactional tustice } \\
\text { Extrinsic job satisfaction }\end{array}$ & 0.19 & 2.63 & & Supported \\
\hline
\end{tabular}

Note: Significant at $t>1.96$ 
Further, the test of predictive relevance that using test Stone-Geisser's to test Q2 was carried out. The value of Q2 for extrinsic job satisfaction is 0.57 , which is greater than 0 , confirming that the model has predictive relevance (Hair et al., 2017).

\section{Discussion and Implication}

This study's findings confirmed that procedural justice, distributive justice, and interactional justice are critical determinants of extrinsic work satisfaction. Conversely, only procedural and interactional justice may operate as indicators of intrinsic job satisfaction, but distributive justice does not. Thus, it can be concluded that the ability of managers or supervisors to execute justice in an organizational system based on norms and guidelines may lead to increased job satisfaction among employees.

This study had provided three crucial implications: theoretical contribution, the robustness of methodology, and practical contribution. Regarding theoretical contribution, this study's findings showed that perceived fairness in the organizational system might enhance job satisfaction intrinsically and extrinsically among employees, but distributive justice does not significantly affect intrinsic job satisfaction. These findings had supported and extended studies by (Qureshi et al., 2018; Afridi \& Baloch, 2018; Ridhwan \& Enah, 2020; Purnama et al., 2020; Krishnan, 2020).

Concerning the robustness of the research methodology, the survey questionnaires employed in this study met the validity and reliability analysis standards satisfactorily. This condition could lead to accurate and trustworthy research findings. In terms of application, the findings of this study can be used to improve the sense of fairness in businesses when it comes to systems management. To reach this goal, improvements must address several critical issues. Firstly, managers should review the decision-making standards and rules to ensure that every legitimate recommendation from staff is considered. Second, the manager or supervisor should be exposed to communication skills to ensure that employees are handled fairly and appropriately. Third, the organization's management should consider how resources were divided to verify that they were given relatively and by employee contributions. If firms take these suggestions seriously and positively adapt them, employee performance in implementing organizational suggestion tactics could skyrocket.

This research put to the test a conceptual framework based on organizational justice research literature. The instrument employed in this investigation passed the validity and reliability tests. Procedural justice, distributive justice, and interactional justice are all critical drivers of extrinsic job satisfaction, according to the SmartPLS path model research. While procedural and interactional fairness has a considerable impact on intrinsic work satisfaction, distributive justice has no such effect. This condition may be influenced by respondents' backgrounds, which may alter their assessment of distributive fairness. Furthermore, managers could concentrate on a different sort of justice (for example, procedural and interactional justice), and government agencies have their wage payment policies. As a result, the influence of distributive fairness on intrinsic job satisfaction may be reduced.

This study had tested a conceptual framework based on the organizational justice research literature. The instrument employed in this study passed the validity and reliability analysis requirements. According to the SmartPLS path model analysis, procedural justice, distributive justice, and interactional justice are essential determinants of extrinsic job satisfaction. While procedural and interactional fairness has a considerable impact on intrinsic work satisfaction, distributive justice has no such effect. This condition may be influenced by respondents' backgrounds, which may alter their assessment of distributive fairness. 
Furthermore, managers could concentrate on a different sort of justice (for example, procedural and interactional justice), and government agencies have their wage payment policies. Besides, other factors may highly influence an employee's intrinsic job satisfaction, such as support from supervisor, great relationship with supervisor and co-worker, and comfortable working environment. As a result, the influence of distributive fairness on intrinsic job satisfaction may be reduced.

Several limitations were mentioned in this study. Firstly, data were collected using a cross-sectional research methodology over the study period at a single moment in time. Second, without examining the impact of moderating or mediating variables, this study solely looked at the direct association between the independent and dependent variables. The mediating or moderating variables can be utilized to test this model to improve the results. Third, this study did not cover other organizational justice outcomes that are important to organizations and employees (e.g., motivation, trust, and performance). Finally, this study's sample was non-random and limited to one organization sector. This conceptual framework can be investigated in other sectors or backgrounds for future research to see if the perception of fairness in organizational justice influences employees' attitudes and behavior in other industries and backgrounds.

\section{Reference}

Ab. Aziz, Y. (2010). Gelagat Organisasi Satu Pendekatan Strategik. Penerbit Universiti Utara Malaysia, Sintok, Kedah, Malaysia.

Adams, J. S. (1963). Toward an understanding of inequity. Journal of Abnormal and Social Psychology, 67(5), 422-436.

Al-Zu'bi, H. A. (2010). A study of the relationship between organizational justice and job satisfaction. International Journal of Business and Management. 5(12), 102-108.

Arif, S., Kundi, O., \& Khan, M. S. (2020). What is the effect of organizational justice and perceived organizational and supervisor support on employee's level of trust?. SEISENSE Journal of Management 3(1): 47-63.

Azman, I., John, C., Ali, B., Osman, M. R., \& Wan, K. W. I. (2011). Kepuasan kerja adalah peramal kepada keinginan berhenti kerja secara sukarela: Satu kajian di sebuah penguasa tempatan. Jurnal Kemanusiaan, 9, 11-26.

Azman, I., Fuad, M. Z., Aimi, A., Al-Banna, H. M., \& Rashidi, A. (2014). Effect of manager's role in performance based pay on employee outcomes. GJAT 4(2), 41-58.

Azman, I., Azmi, N. M. Z., Hilmi, A. H., Nurshahira, I., \& Yusof, I. (2021). Power distance as a moderator in the relationship between organisational justice and job satisfaction. International Journal of Management Studies, 28(1), 25-56.

Bies, R. J., \& Moag, J. S. (1986). Interactional justice: Communication criteria of fairness. Research on negotiation in organizations, 1(1), 43-55.

Chen, S. Y., Wu, W. C., Chang, C. S., Lin, C. T., Kung, J., Y., Weng, H. C., Lin, Y. T., \& Lee, S. I. (2015). Organizational justice, trust, and identification and their effects on organizational commitment in hospital nursing staff. BMC Health Services Research.

Colquitt, J. A., Greenberg, J., \& Zapata-Phelan, C. P. (2005). What is organizational justice: An historical overview. In: Handbook of organizational justice

Donglong, Z., Taejun, C., Julie, A., \& Sanghun, L. (2019). The structural relationship between organizational justice and organizational citizenship behavior in university faculty in China: the mediating effect of organizational commitment. Asian Pasific Education Review, doi: 10.1007/s12564-019-09617-w 
Fornell, C. G., \& Larcker, D. F. (1981). Evaluating structural equation model with unobservable variables and measurement error. Journal of Marketing Research, 18(1), 39-50.

Greenberg, J. (1987). A taxonomy of organizational justice. Academy of Management Review, $1(12), 9-22$

Hair, J. F., Hult, G. T., Sarstedt, M., \& Ringle, C. M. (2014). A Primer Partial Least Squares Structural Equation Modelling (PLS-SEM). America: Sage Publication Inc.

Hair, J. F., Hult, G. T. M., Ringle, C. M., \& Sarstedt, M. (2017). A Primer on Partial Least Squares Structural Equation Modeling (PLS-SEM). Second Edition. Los Angeles: Sage Publication Inc.

Henseler, J., Ringle, C. M., \& Sinkovics, R. R. (2009). The use of partial least squares path modeling in international marketing. Advances in International Marketing, 20, 277-320.

Herzberg, F. (1968). One more time: How do you motivate employees? In S.J. Ott (Ed). Classical Reading in Organizational Behavior. Orlando, Florida: Harcourt Brace \& Company.

Krishnan, H. (2020). The relationship between organizational justice perception and job satisfaction in small and medium enterprises. Journal of Arts \& Social Sciences, 4(1), $31-$ 44.

McShane, S. L., \& Von Glinow, M. A. (2005). Organizational Behavior. Boston: McGraw-Hill Irwin.

Ridhwan, M. A. R., \& Enah, A. (2020). Interdependence between interactional justice and job satisfaction. Management Marketing, XVIII (1), 26-39.

Nadiri, H., \& Tanova, C. (2010). An investigation of the role of justice in turnover intentions, job satisfaction, and organizational citizenship behavior in the hospitality industry. International Journal of Hospitality Management, 29(1), 33-41.

Nawaz, K., Usman, M., Nadeem, M., Nisar, F., \& Saleem, K. (2018). Impact of organizational justice on engineering workers job satisfaction (a research on 100 engineering workers are working in department of electrical at al-arabia sugar mill, noon sugar mill and shakarganj sugar mill manufacturing plants in Sugar Industry of Pakistan). American Journal of Industrial and Business Management, 8, 2209-2230.

Niehoff, B., \& Moorman, R. H. (1993). Justice as a mediator of the relationship between methods of monitoring and organizational citizenship behaviour. Academy of Management Journal, 36(3), 527-556.

Nwibere, B. M. (2014). Organizational justice as a determinant of organizational citizenship behavior in the Nigerian work environment: A study of selected universities in the Niger Delta Region. International Journal of Business and Management, 9(4), 191-205.

Phayoonpun, T., \& Norazuwa, M. (2014). Organizational justice and turnover intention: The mediation role of job satisfaction. International Postgraduate Business Journal, 6 (2), 121

Purang, P. (2011). Organizational justice and affective commitment: the mediating role of perceived organizational support. Asian Academy of Management Journal, 1(16), 141156.

Purnama, Y. H., Tjahjono, H. K., Assery, S., \& Dzakiyullah, N. R. (2020). The relationship of organizational justiceonjob satisfaction and job performance in banking company. International Journal of Scientific \& Technology Research, 9(3)

Qureshi, H., Frank, J., Lambert, E. G., Klahm, C., \& Smith, B. (2016). Organisational justice's relationship with job satisfaction and organizational commitment among Indian police The Police Journal: Theory, Practice and Principles 1-21. doi: 


\subsection{7/0032258X16662684}

Rahim, M. A., Magner, N. R., Antonioni, D., \& Rahman, S. (2001). Do justice relationships with organization-directed reaction differ across U.S. and Bangladesh employees?.The International Journal of Conflict Management, 12(4), 333-349.

Rahman, M., Haque, M., Elahi, F., \& Miah, W. (2015). Impact of organizational justice on employee job satisfaction: An empirical investigation. American Journal of Business and Management, 4(4), 162-171.

Sekaran, U., \& Bougie, R. (2013). Research Methods for Business: A Skill- Building Approach. New York: John Wiley \& Sons, Inc

Spector, P. (1997). Job satisfaction: Application, assessment, causes \& consequences. London: Sage Publications.

Usmani, S., \& Jamal, S. (2013). Impact of distributive justice, procedural justice, interactional justice, temporal justice, spatial justice on job satisfaction of banking employees. Rev. Integr. Bus. Econ. Res, 2 (1), 351-383.

Young, W., Dayo, A., Omotayo, O. A., \& Idowu, F. O. (2019). Influence of distributive justice on job satisfaction: A focus on employees in Nigeria Port Authority. International Journal of Management, 19(3), 69-76. 